\title{
INVESTIGATING MOTIVES FOR PRESERVATION OF JEWISH HERITAGE SITES: THE CASE OF MACEDONIA
}

DOI: http://dx.doi.org/10.18509/GBP.2017.37

UDC: 338.48-53:911.375

\section{Biljana Petrevska ${ }^{1}$ \\ Shaul Krakover ${ }^{2}$ \\ Noga Collins-Kreiner ${ }^{3}$}

${ }^{1}$ Faculty of Tourism and Business Logistics, University Goce Delcev - Štip, Macedonia

${ }^{2}$ Department of Geography and Environmental Development, Ben-Gurion University of the Negev, and Hemdat HaDarom Education College, Israel

${ }^{3}$ Department of Geography and Environmental Studies, University of Haifa, Israel

\begin{abstract}
The study investigates the main motives for preservation of sites of Jewish heritage tourism (JHT) by studying three locations in Macedonia: Skopje (the capital), Stip (the largest city in the east part of Macedonia) and Bitola (the largest city in the southwest part of Macedonia). The article assesses the presence of several motivations, like: (i) Guilt; (ii) Interest in national history; (iii) Revival of a glorious Past; (iv) Economic benefits; (v) Display of sympathy; and (vi) Dark tourism development. The analysis is based on a qualitative research method and incorporates: (a) Qualitative data analysis, by conducting interviews in June 2016 with key stakeholders from central and local governments as the main policy makers; and (b) Analysis of secondary data sources, achieved by reviewing literature, historical, and statistical data related to Jewish history in Macedonia. Generally, the results point to the presence of strong iconic connection among Macedonians and the Jews that lived in Macedonia. The general findings indicate that by establishing and maintaining JH sites, stakeholders reflect sentiments of sympathy and even admiration to the perished Jewish community and a strong desire to revive a glorious past. Only in the case of Bitola, the potential economic benefits were surfaced as the main motive for initiating activities and investments in JH sites. Finally, the study recommends design and development of JHT product and tailor-made tourist packages as key elements that may boost tourism development in Macedonia alongside with commemoration of the Jews and their ties with the Macedonian people.
\end{abstract}

Keywords: JHT, Tourism development, Stakeholders, Macedonia.

\section{INTRODUCTION}

It is now for several decades that more and more places, especially in Europe, are engaged in developing their Jewish heritage $(\mathrm{JH})$ resources [9]. This trend raises questions with respect to the decision makers and steakholders motivations. While visitors' motivation is a widely explored topic [12], motivations of local societies to preserve heritage sites related to others' culture has been barely treated [5]. In the case when central and/or local government politicians are involved in such preservation efforts it signifies that they are not afraid of allegations of being responsible for making investments evoking feelings of dissonance among the local population. Just the opposite, this signifies that according to their discretion such investments will yield positive rewards, not penalties, in terms of public support. 
The primary objective of the study is to provide evidence on prevailing motivations to preserve others' cultural relics though, passingly, light will is shed on the dark tourism perceptions as well. These issues are to be studied in three locations in Macedonia: Skopje, Štip and Bitola. Macedonia represents a suitable test ground for investigating motivations for Jewish heritage tourism (JHT) preservation. On the one hand, it allows generalisation since it resembles other places in Europe were Jewish physical remnents are renovated or rebuilt in the absence of Jews, except for dwindled decendents of Holocaust survivers. On the other hand, it represents a society with charateristics having a potential effect on a study related to motives for preservetion of $\mathrm{JH}$ sites.

Additionally, no academic studies have thus far been carried out on this topic. This is the first attemt to identify the main factors for investing in $\mathrm{JH}$ sites in Macedonia. The practical contribution of the paper lies in the recommendations for designing and developing JHT products that may boost tourism development alongside with commemoration of the Jews and their ties with the Macedonian people.

After the introduction, section two provides a snapshot on the $\mathrm{JH}$ in Macedonia, as a background material. The applied methodology is presented in section three, while the findings and discussion are noted in section four. The last section elaborates the conclusions and recommendations for JHT development in Macedonia.

\section{BACKGROUND MATERIAL}

The Jewish presence in Macedonia dates from the Roman city of Stobi with archeological evidence of a synagogue dating from $2^{\text {nd }}$ to $3^{\text {rd }}$ century AD [10]. The Jewish community remained throughout the Slavic and Byzantine control. Expulsion decrees issued by the Monarchs of Spain in 1492 and Portugal in 1497 combined with the fear of the Inquisition resulted in about 90,000 migrant Jews settling in the Balkans alongside the westward expansion of the Ottoman Empire [7]. These were Ladino-speaking Sephardim Jews who flourished economically and socially in Macedonia, Greece, Serbia, and Bulgaria. By 1910, on the eve of the Balkan wars, some 10,000 Sephardi Jews lived in Macedonia and formed their main communities in the big cities of Skopje [4], Štip and Bitola (known as Monastir).

Jews and gentiles in Macedonia lived peacefully with mutual respect until March 11, 1943 when after 450 years of coexistence they became victims of the Holocaust. At that time, 3,242 Jews from Skopje, 551 from Štip and 3,351 from Bitola, or total of 7,144 Jews ( $98 \%$ of the total Jewish population living in Macedonia at that time) were deported to their execution in the concentration camp of Treblinka, Poland. At the end of WWII only 140 Jews, mostly Partisans, survived, most of them immigrated to Israel. Today, the Jewish community of Macedonia numbers 250, out of which about two thirds belong to assimilated families.

\section{METHODOLOGY}

The selected research area is composed of three cities richly endowed with JH: Skopje, Štip and Bitola (Fig. 1), each with its own story and specific JH resources.

Skopje (Fig. 1, No 1), the capital of Macedonia, is the economic and administrative center with a large ethnic diversity. The current Macedonian Jewish community is located here with around 200 Jews. There are two main JH sites associated with developing JHT: (1) The Holocaust Memorial Centre of the Jews from Macedonia; and (2) The Beit Yaakov Synagogue. 
Štip (Fig 1, No 2) is the largest city in the east part of Macedonia serving as a cultural and economic center of the eastern region. After the deportation in 1943, out of 131 families, only one family was registered in the city up to 2009, while today no Jews actively live in this city. There are two JH sites associated with developing JHT: (1) The Monument of Deported Jews ("Line of Life"); and (2) The Jewish cemetery.

Bitola (Fig 1, No 3) is a city in the southwestern part and one of the oldest in Macedonia. It was a lively center with a long history of the Jews living in the city. There are several JH sites: a commemorative plaque that was unveiled on columns that remained from the "Kahal Kadosh Aragon" synagogue, situated in the city park known as The Columns; the Monument of Deported Jews; the Old Jewish Houses in Sirok Sokak (Wide Alley); and the Jewish cemetery with a small museum named Memorial Park of the Jews from Bitola. In 1997, an initiative was raised to restore the cemetery and to create a memorial park "Park of the living memories".

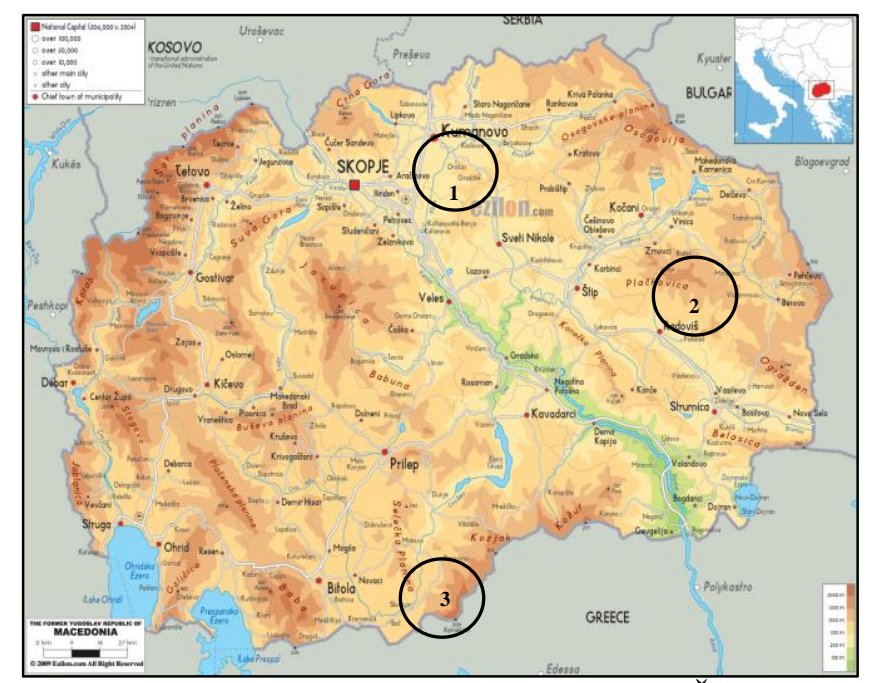

Figure 1. Research locations: 1- Skopje, 2-Štip, 3-Bitola

In order to identify the prevailing motives for preserving $\mathrm{JH}$ sites, the study is based on a qualitative research method incorporating two sources of data: interviews and secondary sources. Total of 18 interviews were conducted in June 2016, with a conversation time ranging from 20-120 minutes. The target group consisted of key stakeholders from the central and local government levels who were identified as the main policy makers for investing in the development and preservation of JH sites. Specifically, they are: presidents and members of city council, a Mayor, municipal heads for tourism development offices, municipal councilor for culture, state advisor for tourism, representative from the National agency for tourism, executive director of the chamber of tourism, and the director of the Commission for relationship with religious groups and communities. In the case of Skopje, the interviewees at the local level were members of the city council of Skopje and they gave responses just for Skopje as one of the sampled locations. The interviewees at the central government level - holding positions in central institutions in Skopje - were simultaneously able to provide responses for Macedonia in general, and for Skopje in particular. In the case of Štip and Bitola, all respondents belong to the local government administration. In addition to the target group, five interviews were undertaken with persons holding different positions referred to as sources of information. 
During the interviews, full notes were taken, upon which a qualitative data analysis was conducted encompassing two steps: summarization and compilation. Information obtained through the interviews and secondhand material drawn from publications, was summarized into items. Then the items having closely similar themes were categorized together in order to draw conclusion. The interviews were undertaken during open-ended questioning sessions, which allowed collection of more subjective and qualitative data. Prior to entering the field survey, an interview protocol was prepared. The interviews contained clear and direct questions, tailored to draw conclusions regarding the following hypotheses concerning motives for preservation of JH sites:

$\mathrm{H}_{1}$ : Motivation driven by guilt suggested by [1] as "atonement for active or passive collaboration in genocide";

$\mathrm{H}_{2}$ : Interest in national history [8];

$\mathrm{H}_{3}$ : Revival of a harmonious Past when people of different affiliations were living in harmony [8];

$\mathrm{H}_{4}$ : Economic motivation to have one more point of interest or attraction for tourists visiting the city and especially for Jewish visitors as a special interest group [3];

$\mathrm{H}_{5}$ : Display of respect towards Jews as a tool in the struggle on hegemony and power among the larger religious segments living in the city or country [11]; and,

$\mathrm{H}_{6}$ : A part of the growing interest in Dark tourism of visiting sites that are connected to a Jewish Holocaust [2], [6].

\section{FINDINGS AND DISCUSSION}

The findings were analyzed in two stages. In the first, the interview material was searched for the detection of any one of the six motives outlined earlier. In the second stage, a comparison analysis of the results was made leading to general conclusion with respect to the prevailing motives for $\mathrm{JH}$ preservation in Macedonia.

Stage 1: Following a process of data filtering, it was found that two hypotheses $\left(\mathrm{H}_{3}\right.$ and $\mathrm{H}_{5}$ ) were the main ones for all three case studies. Decision-makers in Macedonia chose to emphasize that they are supporting initiatives for investing in $\mathrm{JH}$ sites mainly due to the motives of 'respect' and 'revival of harmonious past'. Below the motives are listed from the most common to the least ones:

- $\quad H_{5}$ : Displaying respect towards the Jews from the local community.

○ This motive appears to be the main one in Skopje. The following sentences represent support of this motive: "The story [of the local Jews] must be told"; "The Memorial Center in Skopje serves to honor and commemorate the Macedonian Jews"; "A personalization of the Jewish tragedy is what gives the power to the story" and "Macedonia honors the dead Jews by setting an example to which other nations could and should aspire".

- This motive is also the main motive in Štip. When mentioning the Jews' tragic history, it was met with lots of sympathy and reverence regarding these former highly respected citizens. All interviewees left the impression that they still cherish the good memories Jews left behind. For example: We want to pay respect to those citizens who acted as a role model and left footprints on Štip's cultural and economic development"; and "It shouldn't be forgotten since it shouldn't be repeated!"

○ This motive is strongly supported by $80 \%$ of the respondents in Bitola. Their respect can be supported with the following sayings: "To keep and remember"; "Never to forget the memories"; "To pay respect". In short a repeated theme reflecting respect is expressed by the sentence: "The [local] Jewish story must be told and remembered". 
- $\quad H_{3}$ : The revival of the harmonious Past when different affiliations were living along in harmony.

$\circ \quad$ This was found as an additional leading motive in all three case studies. In Skopje, this motive was chosen by all respondents both on local and national levels. Jews lived in Skopje for centuries mostly concentrated in a well-established neighborhood and became a vital part of the local community. This was expressed as follows: "To preserve the memory of the Jews of Macedonia, not only commemorate their death, but also their lives and the civilization that perished with them"; "To keep the memory of the Jews, their traditions, and their two-millennium long contribution to the co-existence all segments of society"; "Despite the modest and limited investments in JH sites, this is a payback to Jews loyalty as citizens".

- In Štip, this is the second most important motive selected by $67 \%$ of respondents. Here, investing in JH may be justified with the presumption to keep the good memory of a community that lived along with the locals in the past. This can be supported with the following sentences: "We want to preserve the memories for the next generations about a noble, honest and friendly community"; and "The Monument of Deported Jews testifies for a harmonious time when Jews left cultural footprints in the municipality".

$\circ$ In Bitola, this is a strong motive pointed out by $80 \%$ of the interviewees, which was expressed in the following examples: "The Jews were very important in the life and culture of Bitola"; and "The Jews played important role in the historic past of Bitola".

\section{- $\quad H_{4}$ : Economic benefits}

- No return of investments is expected with respect to the JH sites in Skopje. Education, and not tourist valorization, is the lead objective stated in the working program of the main JH site in Skopje/Macedonia - the Memorial center. Having in mind that this is the most remarkable JH site in Skopje/Macedonia and can be visited free of charge, it accentuates the finding that no financial benefits were expected.

○ In Štip, half of the respondents partially considered the economic return to investments. Namely, they partially agree that JH sites may be developed as points of interest or tourist attractions, but only if being a part of a much larger context such as cultural tourism.

○ In Bitola all respondents pointed out economic benefits as the main reason for making investments in sites related to JHT. This can be supported with the following sentences: "The local self-government unit (LSGU) will support every activity related to the Jewish heritage that brings positive benefits to the citizens, in line with their economic well-being"; "To create a complex that will remind of the past that evokes pleasant memories, and at the same time to develop the place into a tourist attraction out of which local people will benefit"; "To build a home of living memories that will be selfsustainable leading to local economic development"; and "By making Bitola recognizable with the JH tourist sites, the municipality will economically grow".

- $\quad H_{6}$ : Dark tourism (the intention was to investigate to what extend JH sites are associated to this concept).

○ Only 14-20\% of the respondents from Skopje associated the JHT with dark tourism. The main reason for objecting this notion is related to the lack of a significant horror story that may serve as a base for developing dark tourism. Namely, the Memorial center is generally used for educational purposes in line of everyday life of Jews in Macedonia and less about the Holocaust.

- Similarly, in Štip, the general attitude was that there are only memorial landmarks which present a memory of a tragic event, while nothing directly, explicitly happened in 
the city. Half of the respondents partially agree that dark tourism may be initiated in Štip but only if many preconditions are fulfilled, like: raising awareness about the concept of dark tourism, and establishing closer cooperation with relevant institutions at regional and national level for identifying a 'complex' dark tourism product.

- Just one respondent argued that Bitola has potentials for developing dark tourism, but a development strategy is missing. Despite having darkness in the Jews' story, some interviewees were explicit that it cannot be used as a starting point to develop dark tourism. Accordingly, some think that the Jewish cemetery cannot stand as a solo site for developing dark tourism, but only if there is a story with much broader context. However, none was sure about the way the story can be interpreted.

\section{- $\quad H_{1}$ : Guilt / $H_{2}$ : Facing national history}

- No presence was found of motives driven by guilt pointing to have no motivation such as "atonement for active or passive collaboration in genocide". The respondents felt no guilt for the Holocaust since at the time of deportations, Macedonia was under Bulgarian occupation.

$\circ \quad$ A slight presence was found to the motive of "facing national history" $\left(\mathrm{H}_{2}\right)$. Only one person in Štip admitted that preserving Jewish sites was a partially deliberate decision to face chapters in national history harsh as they may be.

Stage 2 comprised of a comparative analysis as reflected in Table 1. The findings revealed that the same two hypotheses $\left(\mathrm{H}_{3}\right.$ and $\left.\mathrm{H}_{5}\right)$ are confirmed for all three case studies, leading us to a general conclusion that counts for Macedonia as a country. Namely, there were strong relations between the citizens of Macedonia as a whole and the perished Jewish community, based upon declared memories of harmonious relationships. The respondents from all sampled locations expressed respect for the spiritual, cultural and intellectual contribution of the Jews by making statements of admiration and readiness to invest for commemorating of a respectful coexistence in the past. Keeping the memory of the Jews along with displaying respect, are the main motives for preserving the cultural assets of a minority that almost disappeared.

Hence, it appears that Macedonians substituted the atrocious, tragic and dark past of the Jewish community and transform it into memories of human heroism, dignity and respect. The overall findings point to the fact that there is no future without memories. One must not stop remembering, it is a warning for future generations, to know how to express regret for the suffering and loss and at the same time to commit to remembering the victims.

Table 1. Comparative analysis of the results

\begin{tabular}{|c|c|c|c|c|c|c|}
\hline \multicolumn{2}{|c|}{ Hypothesis } & \multicolumn{2}{|c|}{ Skopje $*(n=7)$} & Štip $(n=6)$ & Bitola $(n=5)$ & $\sum n=18 * *$ \\
\hline \multirow{2}{*}{$\begin{array}{l}\stackrel{\Xi}{\Xi} \\
\ddot{\Xi} \\
\ddot{\bar{I}}\end{array}$} & Qn & $\begin{aligned} \text { Local: } & \\
\text { No } & =43 \% \\
\text { No response } & =57 \%\end{aligned}$ & $\begin{aligned} \text { Central: } & \\
\text { No } & =40 \% \\
\text { No response } & =60 \%\end{aligned}$ & $\begin{aligned} \text { Yes } & =17 \% \\
N o & =50 \% \\
\text { No response } & =33 \%\end{aligned}$ & $\begin{aligned} N o & =40 \% \\
\text { No response } & =60 \%\end{aligned}$ & No $=43 \%$ \\
\hline & Q1 & \multicolumn{2}{|c|}{ No presence } & No presence & No presence & NO PRESENCE \\
\hline \multirow{2}{*}{ 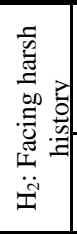 } & Qn & $\begin{aligned} \text { Local: } & \\
\text { Yes } & =14 \% \\
\text { No response } & =86 \%\end{aligned}$ & $\begin{aligned} \text { Central: } & \\
\text { Yes } & =20 \% \\
\text { No response } & =80 \%\end{aligned}$ & $\begin{aligned} \text { No } & =17 \% \\
* * * \text { Partially } & =34 \% \\
\text { No response } & =49 \%\end{aligned}$ & No response $=100 \%$ & $\begin{array}{l}\text { Yes }=17 \% \\
\text { Partially taken as } \\
\text { half yes, half no } \\
\text { No response ignored }\end{array}$ \\
\hline & Q1 & \multicolumn{2}{|c|}{$\begin{array}{l}\text { Only } 1 \text { respondent gave an open discussion } \\
\text { that it was a deliberate decision to face harsh } \\
\text { history for Skopje and Macedonia }\end{array}$} & Partially & No clear statement & Slightly present \\
\hline$\therefore \begin{array}{ll}3 \\
9\end{array}$ & Qn & $\begin{array}{l}\text { Local: } \\
\text { Yes }=100 \%\end{array}$ & $\begin{array}{l}\text { Central: } \\
\text { Yes }=100 \%\end{array}$ & $\begin{aligned} Y e s & =67 \% \\
\text { No response } & =37 \%\end{aligned}$ & $\begin{aligned} \text { Yes } & =80 \% \\
\text { No response } & =20 \%\end{aligned}$ & Yes $=87 \%$ \\
\hline
\end{tabular}




\begin{tabular}{|c|c|c|c|c|c|c|}
\hline & Q1 & \multicolumn{2}{|c|}{ Main motive } & Main motive & Main motive & MAIN MOTIVE 2 \\
\hline \multirow{2}{*}{ 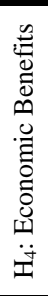 } & Qn & $\begin{aligned} \text { Local: } & \\
\text { No } & =71 \% \\
\text { No response } & =29 \%\end{aligned}$ & $\begin{aligned} \text { Central: } & \\
\text { No } & =60 \% \\
\text { No response } & =40 \%\end{aligned}$ & $\begin{aligned} \text { No } & =17 \% \\
\text { Partially } & =50 \% \\
\text { No response } & =33 \%\end{aligned}$ & $Y e s=100 \%$ & No $=43 \%$ \\
\hline & Q1 & \multicolumn{2}{|c|}{$\begin{array}{c}\text { Investment in } \mathrm{JH} \text { is not lead by economic } \\
\text { motive }\end{array}$} & $\begin{array}{l}\text { Partially agree that JH sites } \\
\text { may be developed as points } \\
\text { of interest or tourist } \\
\text { attractions, but only if being } \\
\text { a part of a much larger } \\
\text { context (ex: cultural tourism) }\end{array}$ & Main motive & $\begin{array}{l}\text { Only in small cities } \\
\text { (as Štip and Bitola), } \\
\text { economic benefit may } \\
\text { be a kind of a leading } \\
\text { motive for } \\
\text { investment in } \mathrm{JH}\end{array}$ \\
\hline \multirow{2}{*}{ 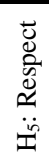 } & Qn & $\begin{array}{l}\text { Local: } \\
\qquad \text { Yes }=100 \%\end{array}$ & $\begin{array}{l}\text { Central: } \\
\quad Y e s=100 \%\end{array}$ & Yes $=100 \%$ & $\begin{aligned} & Y e s=80 \% \\
& \text { No response }=20 \% \\
&\end{aligned}$ & Yes $=95 \%$ \\
\hline & Q1 & \multicolumn{2}{|c|}{ Main motive } & Main motive & Main motive & MAIN MOTIVE 1 \\
\hline \multirow{2}{*}{ 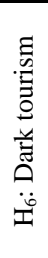 } & Qn & $\begin{aligned} \text { Local: } & \\
\text { Yes } & =14 \% \\
N o & =43 \% \\
\text { Don't know } & =14 \% \\
\text { No response } & =29 \%\end{aligned}$ & $\begin{aligned} \text { Central: } & \\
\text { Yes } & =20 \% \\
N o & =40 \% \\
\text { Don't know } & =20 \% \\
\text { No response } & =20 \%\end{aligned}$ & $\begin{aligned} \text { Yes } & =17 \% \\
\text { No } & =17 \% \\
\text { Partially } & =50 \% \\
\text { Don't know } & =16 \%\end{aligned}$ & $\begin{aligned} \text { Yes } & =20 \% \\
N o & =40 \% \\
\text { Partially } & =20 \% \\
\text { Don't know } & =20 \%\end{aligned}$ & No $=35 \%$ \\
\hline & Q1 & \multicolumn{2}{|c|}{$\begin{array}{l}\text { No dark tourism may be developed in the } \\
\text { case of Skopje, nor in Macedonia in general }\end{array}$} & $\begin{array}{c}\text { Partially, if numerous } \\
\text { preconditions are previously } \\
\text { fulfilled }\end{array}$ & $\begin{array}{l}\text { No possibilities for } \\
\text { dark tourism } \\
\text { development }\end{array}$ & $\begin{array}{l}\text { NO DARK } \\
\text { TOURISM }\end{array}$ \\
\hline
\end{tabular}

Note: Qn-Quantitative findings; $Q l$ - qualitative assessment

* Out of total 7 respondents, 2 were at local level, and 5 at central level. However, the respondents at central level simultaneously gave opinion for Skopje as a sample location, and for Macedonia in general.

That is the main and only reason for mismatching the number of responses on each hypothesis.

**Given the similar number of respondents, the average response rate has been calculated as a simple average of the three/four case studies.

*** For the sake of quantitative comparisons, the percentage partially agreeing with a motivation was divided equally between Yes and No. No response was ignored.

\section{CONCLUSION AND RECOMMENDATIONS}

Based upon the research findings, the following conclusions are reached:

○ Decision-makers in Macedonia chose to emphasize that they are supporting initiatives for investing in JH sites due to two motives: expression of Respect towards Jews, and Revival of a Harmonious Past when people of different affiliations were living in harmony.

- The economic motivation was found to be present only in the smaller cities (as in Stip - partially, and in Bitola - as the main motive), which is not the case of Skopje. The smaller cities representatives seems to believe that $\mathrm{JH}$ sites may be developed as points of interest for tourist attractions, thus attracting visitors and especially Jewish tourists as a special interest group that may assist in alleviating their standard of living.

$\circ$ No other motives were found for developing JHT in Macedonia though the authors hypothesized that guilt and facing harsh national history may also prevail as motives found in other countries.

- The studied JH sites are not perceived to be associated with dark tourism, nor possibilities for its development are noted due to the lack of a significant dark history that may serve as a base for developing dark tourism.

Furthermore, based on objective screening, it was concluded that all sampled locations do not offer autochthonous and competitive tourist offer, so initiating JH tourist product may be thought of as a key element that will support and enhance tourism development. The present practice may be defined as uncoordinated and unorganized, whereas the regional/national aspect is missing. Long-term planning imposes the need of creating 
clearly defined and recognizable supply by designing tailor-made tourist packages as JH tourism route. Preparation of adequate promotional material which will provide more information about the life of the Jews may generate a possibility to attract tourists. Macedonia may promote and offer its well-kept Jewish story as a spiritual heritage. In addition, the study recommends to urge initiatives to include Macedonia in the regional tours which usually encompass Bulgaria, Serbia and Greece. Namely, Macedonia is a small country with still limited JH potentials that may be insufficient for creating a selfstanding JHT offer. The solution may be seen in the broader regional context. Hence, developing JHT may be beneficial as it can strengthen local and national economy, increase visitors' consumption, and generate employment. This will surely help increase awareness of residents for the $\mathrm{JH}$ which they possess.

\section{REFERENCES}

[1] Ashworth, G. J. 2003. Heritage, identity and places: For tourists and host communities. In S. Singh, D.J. Timothy, \& R.K. Dowling (Eds.), Tourism in Destination Communities (pp. 79-97). Wallingford: CABI

[2] Collins-Kreiner, N. 2016. Dark Tourism as/is Pilgrimage, Current Issues in Tourism 19, 12: 1185-1189

[3] Dinis, A., and Krakover, S. (2016). Niche Tourism in Small Peripheral Towns: The Case of Jewish Heritage in Belmonte, Portugal. Journal of Tourism Planning and Development. 13(3), 310-332. DOI: 10.1080/21568316.2015.1114014

[4] Frank, C. 2010. Anti-Semitism in Yugoslavia. Antisemitism in Eastern Europe: History and Present in Comparison, 5, 67.

[5] Gruber, R. E. 2002. Virtually Jewish: Reinvention of Jewish culture in Europe. Berkeley and Los Angeles: University of California Press.

[6] Hartmann, R. 2014. Dark tourism, thanatourism, and dissonance in heritage tourism management. Journal of Heritage Tourism, 9(2), 166-182.

[7] Hupchick, D. P. 2002. The Balkan Peoples under the Ottomans. In: The Balkans (pp. 144-163). Palgrave Macmillan US.

[8] Krakover, S. 2013. Jewish heritage tourism in Spain and its relations to peace and reconciliation. Paper presented at the Peace Conference, University of Wageningen, October 9-11, Wageningen, The Netherlands.

[9] Krakover, S. 2016. Heritage site development model: Jewish heritage product formation in South-Central Europe. Journal of Heritage Tourism, 11(4), Published online: http://dx.doi.org/10.1080/1743873X.2016.1151430

[10] Ovadiah, A. 2015. Ancient Jewish Communities in Macedonia, Thrace and Upper Epirus. Gerion, 33, 211-227.

[11] Papo, E. 2016. Oral exchange with Shaul Krakover at Ben-Gurion University of the Negev, Beer Sheva, Israel.

[12] Poria, Y., Reichel, A., \& Biran, A. (2006). Heritage site management: Motivations and expectations. Annals of Tourism Research, 33(1), 162-178. 